\title{
Drug Firm Sponsorship of College Activities: Guidelines*
}

1. Whenever possible money should be used to improve the quality of scientific activities rather than the level of hospitality and social events, e.g. by paying for speakers' expenses, hire of premises, circulation of notices, provision of visual aids, etc.

2. The approach to a drug firm or firms for support should be by an Officer of the College or one of its Divisions, Sections, Groups or other Committees (e.g. Collegiate Trainees, Psychiatric Tutors, etc).

3. To avoid problems with the Inland Revenue and to enable the College to portray the College activities in full, all financial transactions should be handled by the Treasurer's Office, who will produce detailed accounts of any meetings on request.

4. Appropriate acknowledgement of the source of sponsorship may appear on the notice of any meeting (or social function) so sponsored.

5. At no time should acceptance of sponsorship by the

*Approved by Council June 1985.
College be portrayed by the sponsor as an endorsement by the College to their products.

6. Where meetings are held in hospitals the choice of speakers and the decision whether or not to use private caterers should remain under the control of the doctor organizing the meeting. Valuable guidelines on this and other aspects are contained in the 'Report of the Working Party on the Role of the Pharmaceutical Industry in Postgraduate Medical Education' published by and obtainable from the Medico-Pharmaceutical Forum, 1 Wimpole Street, London, W1M 8AE.

7. Where a drug firm organizes its own meeting and invites speakers, defrays participants' expenses or provides hospitality the College name should not be used or acknowledged.

8. The help of the pharmaceutical industry in supporting medical educational activities is understood and appreciated but the overriding consideration where the College is concerned is that the choice of the scientific programme and the level of hospitality and advertising should be controlled by College officials.

\section{Obituary}

Harold Charles Beccle, formerly Physician Superintendent, Springfield Hospital, London SW17.

Harold Beccle, who died in Cornwall at the age of 83, had been the last Superintendent (the fifth only since the post was introduced in 1863) of Springfield Hospital before his retirement in 1968. He qualified at Guy's in 1923, where he had been Senior War Memorial Scholar, and worked there in the Casualty and Morbid Histology Departments before spending several years at the West End Hospital where he gained the MRCP. His interest in neurology, leading at that time to studies in various contemporary problems (such as encephalitis lethargica and the malarial treatment of GPI), persisted through his career and he might well have become a physician However, he entered psychiatry with an appointment at Bethlem and subsequently became Medical Officer to what was then the observation ward in Paddington General Hospital.

After several years there and at Maidstone, he joined Springfield in 1933. Conditions there were much as they had been for decades and it was not until after the war, when he returned from the RAF, that he became Superintendent and had the opportunity to initiate many overdue developments. Of these, the Rehabilitation Unit and Industrial Workshops are the most conspicuous, but many of the changes that brought Springfield into the present era are attributable to him.

Although personally reserved, he was an intelligent and cultivated companion: an initially defensive exterior concealed a capacity for warmth, informality, friendship and great kindness.

ICLP
Narcyz Lukianowicz, formerly Consultant Psychiatrist, Holywell Hospital, Antrim.

Dr Narcyz Lukianowicz died in Cambridge on 24 July 1985 at the age of 78 .

He was born in Western Ukraine. After classical studies in grammar school, he went on to the medical course at the University of Lvov which he completed in 1932. His first post was with Professor Wagner-Jauregg, and he went on to write an MD thesis on 'Mental Illness and Crime' while a junior lecturer. In 1938 he became 'Primarius' of a new neurological unit in Lvov and two years later also undertook teaching duties at the University of Lvov, posts which he continued during the Russian and German occupations. In 1944 he took a post in Vienna at the University's neuropsychiatric department and also worked in the Maria-Theresienschlossel psychiatric hospital.

He went 'underground' for various reasons in 1946, and moved to Austrian Carinthia, working as a neuropsychiatrist for UNRRA in the British Occupational Zone. Then he went on to join the First Polish Corps under General Anders in Italy, and at the end of hostilities was transferred to the United Kingdom. After demobilization he established a neuropsychiatric unit, set up by the British and Polish governments in Brighton, for the rehabilitation of Polish soldiers, and continued as medical superintendent until the unit was disbanded in 1951 .

He entered the National Health Service as a registrar in Bristol in 1952 and gained a consultant post in 1962 at Holywell Hospital, Antrim. He initiated several new services there, including postgraduate teaching, family therapy and 